\title{
Screening of cloud microorganisms isolated at the Puy de Dôme (France) station for the production of biosurfactants
}

\author{
Pascal Renard ${ }^{1,2}$, Isabelle Canet ${ }^{1}$, Martine Sancelme ${ }^{1}$, Nolwenn Wirgot ${ }^{1,2}$, Laurent Deguillaume ${ }^{3}$, and \\ Anne-Marie Delort ${ }^{1,2}$ \\ ${ }^{1}$ Institut de Chimie de Clermont-Ferrand, Université Clermont Auvergne, Université Blaise Pascal, BP 10448, \\ 63000 Clermont-Ferrand, France \\ ${ }^{2}$ CNRS, UMR 6296, ICCF, 63171 Aubière, France \\ ${ }^{3}$ Laboratoire de Météorologie Physique/OPGC, Université Clermont Auvergne, Université Blaise Pascal, BP 10448, \\ 63000 Clermont-Ferrand, France
}

Correspondence to: Anne-Marie Delort (a-marie.delort@univ-bpclermont.fr)

Received: 25 May 2016 - Published in Atmos. Chem. Phys. Discuss.: 27 May 2016

Revised: 7 September 2016 - Accepted: 8 September 2016 - Published: 29 September 2016

\begin{abstract}
A total of 480 microorganisms collected from 39 clouds sampled at the Puy de Dôme station (alt. $1465 \mathrm{~m}$; $45^{\circ} 46^{\prime} 19^{\prime \prime} \mathrm{N}, 2^{\circ} 57^{\prime} 52^{\prime \prime} \mathrm{E}$; Massif Central, France) were isolated and identified. This unique collection was screened for biosurfactant (surfactants of microbial origin) production by measuring the surface tension $(\sigma)$ of the crude extracts, comprising the supernatants of the pure cultures, using the pendant drop technique. The results showed that $41 \%$ of the tested strains were active producers $\left(\sigma<55 \mathrm{mN} \mathrm{m}^{-1}\right)$, with $7 \%$ being extremely active $\left(\sigma<30 \mathrm{mN} \mathrm{m}^{-1}\right)$. The most efficient biosurfactant producers $\left(\sigma<45 \mathrm{mN} \mathrm{m}^{-1}\right)$ belong to a few bacterial genera (Pseudomonas and Xanthomonas) from the $\Upsilon$-Proteobacteria class $(78 \%)$ and a yeast genus (Udeniomyces) from the Basidiomycota phylum (11\%). Some Bacillus strains from the Firmicutes phylum were also active but represented a small fraction of the collected population. Strains from the Actinobacteria phylum in the collection examined in the present study showed moderate biosurfactant production $\left(45<\sigma<55 \mathrm{mN} \mathrm{m}^{-1}\right)$. Pseudomonas $(\Upsilon$-Proteobacteria), the most frequently detected genus in clouds, with some species issued from the phyllosphere, was the dominant group for the production of biosurfactants. We observed some correlations between the chemical composition of cloud water and the presence of biosurfactantproducing microorganisms, suggesting the "biogeography" of this production. Moreover, the potential impact of the production of biosurfactants by cloud microorganisms on atmospheric processes is discussed.
\end{abstract}

\section{Introduction}

Atmospheric aerosol particles act as cloud condensation nuclei $(\mathrm{CCN})$ upon which liquid droplets can form. The presence of more aerosols increases the concentration of smaller droplets, leading to a brighter cloud (the Twomey effect). However, owing to their complexity, all aerosol-cloud interactions (ACIs) can amplify or dampen this effect. Therefore, ACIs, particularly CCN activation, still account for major uncertainties in global climate and future climate change predictions (Boucher et al., 2013).

Among organic aerosols, water-soluble organic compounds (WSOCs) represent a significant fraction of the tropospheric aerosol mass (Kanakidou et al., 2005; Murphy et al., 2006; Saxena and Hildemann, 1996; Zenchelsky and Youssefi, 1979; Zhang et al., 2007) and constitute a complex mixture of neutral and acidic polar organic compounds (Decesari et al., 2001). As some WSOCs are amphipathic compounds, these aerosols can act as surfactants (surface-active agents) by creating a partition between the droplet gas-liquid interface and the bulk volume. Seidl and Hänel (1983) were among the first to estimate concentrations of surface-active soluble substances on rainwater and wet aerosol by measuring the lowering of the surface tension. Capel et al. (1990) correlated the surface tension of fog samples with the dissolved organic carbon content. Hitzenberger et al. (2002) observed slight reductions in the surface 
tension for most of the 23 cloud water samples collected in mountainous and sparsely populated areas.

Some groups (Decesari et al., 2005; Facchini et al., 1999) have renewed research on surface-active compounds in the atmosphere with a great deal of speculation about the potential impact of these compounds on the climate (Brimblecombe and Latif, 2004). Indeed, surfactants affect cloud droplet growth in two main ways according to the Köhler equation (Köhler, 1936): by increasing soluble mass (the "Raoult term") and by decreasing cloud droplet surface tension (the "Kelvin term") (Decesari et al., 2003; Facchini et al., 1999; Lance et al., 2004; Mircea et al., 2002; Rodhe, 1999; Shulman et al., 1996). Thus, considering both the solute concentration increase and the surface tension decrease, Mircea et al. (2002) calculated a substantial attenuation of the aerosol critical supersaturation, revealing a significant increase in the $\mathrm{CCN}$ number concentration. By adding surfactant to the gas-aerosol interface, Sareen et al. (2013) assessed significant enhancements in CCN activity (up to $7.5 \%$ reduction in critical dry diameter for activation), which for ambient aerosol would lead to a $10 \%$ increase in the cloud droplet number concentration. Facchini et al. (1999) estimated that a population rise resulting from surfactants might result, in all stratus clouds, in a $1 \%$ increase in albedo and, subsequently, in a calculated global radiative forcing of $-1 \mathrm{~W} \mathrm{~m}^{-2}$.

In addition to the impact of surfactants on $\mathrm{CCN}$ activity via both the Raoult and the Kelvin term, a third effect should be considered. Surfactants can either enhance or slow down the transfer of water across the surface according to the hydrophilic or hydrophobic nature of this aerosol organic coating (Aumann and Tabazadeh, 2008; Chakraborty and Zachariah, 2011; Feingold and Chuang, 2002; Rudich, 2003). These organic coats are common on aerosol particles and might retard the evaporation of molecules present in the water phase, reduce gas transfer, influence chemical reactions, and alter absorption or reflection properties of aerosols (Clifford et al., 2007; Decesari et al., 2003; Gill et al., 1983; Gilman and Vaida, 2006). Nenes et al. (2002) examined the sensitivity of the cloud droplet number concentration to different chemical factors as the dissolution of soluble gases and solutes or formation of organic films at the droplet surface, demonstrating that these chemical effects on droplet activation could be significant. Similarly, the ${ }^{\bullet} \mathrm{OH}$ heterogeneous reactions that occur on organics in the troposphere can significantly modify the hygroscopic properties and CCN ability of these organic surfaces (Bertram et al., 2001; Ellison et al., 1999), thus potentially playing an important role in the Earth's radiative balance by affecting the properties of clouds, e.g., the Twomey effect and cloud lifetime (Aumann et al., 2010; Nenes et al., 2002; Rodhe, 1999).

Recent experiments have focused on $\mathrm{CCN}$ enhancement resulting from biogenic influence (Facchini et al., 2000; O'Dowd et al., 2002; Svenningsson et al., 2006). Thus, some atmospheric organic compounds, such as pinic and pinonic acids (produced by the oxidation of terpenes in organic va- pors released from the canopy), have been implicated in the reduction of the surface tension of water, even at extremely low concentrations ( $\mathrm{Li}$ et al., 2010; O’Dowd et al., 2002). Another important class of hydrophobic WSOCs is humiclike substances (HULIS). These complex mixtures of highmolecular-weight compounds can depress surface tension in fog water samples by 15-20\% (Decesari et al., 2003; Dinar et al., 2006; Facchini et al., 2000).

Nevertheless, although a number of organic surface-active compounds have been detected in aerosol particles and cloud droplets, a large fraction of WSOCs remain poorly characterized (Herckes et al., 2013). Moreover, due to their limited concentrations in aerosols, it remains unknown whether atmospheric organic surfactants decrease the surface tension of atmospheric water or contribute to the $\mathrm{CCN}$ properties of atmospheric particles (McFiggans et al., 2006).

In the last decade, a few studies have identified strong organic surfactants in atmospheric aerosols (Baduel et al., 2012). Their exceptional tension-active properties suggested that these compounds could be "biosurfactants" of microbial origin that could affect cloud formation (Ekström et al., 2010; Nozière et al., 2014). Biosurfactants are secondary metabolites produced by microorganisms, including low-molecular-mass biosurfactants (mainly glycolipids and lipopeptides) and high-molecular-mass biosurfactants (polysaccharides, proteins, lipopolysaccharides, lipoproteins or complex mixtures of these polymers) (Gautam and Tyagi, 2006; Rosenberg and Ron, 1999). These amphiphilic compounds reduce the surface tension of atmospheric water below $30 \mathrm{mN} \mathrm{m}^{-1}$ (i.e., $>-40 \%$ compared with pure water) and at concentrations 5 or 6 orders of magnitude lower than organic acids (Ekström et al., 2010). In comparison, HULIS decreased the surface tension in fog water samples by $20 \%$ at $100 \mathrm{mg} \mathrm{C} \mathrm{L}^{-1}$ (Facchini et al., 2000).

Baduel et al. (2012) measured the surface tension in summer samples, which would be consistent with the highbiogenic activity observed during this season. Ahern et al. (2007) showed that fluorescent pseudomonads isolated from clouds and rainwater produce biosurfactants. This study was the first and sole report on the exploration of the potential production of biosurfactants by microorganisms isolated from the cloud environment. Biosurfactants could be directly issued from the Earth's surface during aerosolization or directly produced in cloud waters. However, a multitude of bacteria, fungi, and yeasts display metabolic activities in clouds (Amato et al., 2005, 2007a; Hill et al., 2007; Sattler et al., 2001; Vaïtilingom et al., 2012, 2013). These microorganisms survive and resist atmospheric stresses (Delort et al., 2010; Joly et al., 2015).

Poorly considered in the atmosphere, biosurfactants have been extensively studied in soil- and plant-associated environments. Indeed, biosurfactant-producing bacteria in both undisturbed and contaminated soils have been well characterized (Bodour et al., 2003; Raaijmakers et al., 2010). Biosurfactants have been investigated for their capacity to re- 
move heavy metals, and bioremediation is one of the main industrial applications of biosurfactants (Banat et al., 2010; Mulligan, 2009). Moreover, in terms of microbial life and activity, biosurfactants play a key role in bacterial cell motility, organic compound solubilization, microbial biofilm formation, and disruption or antimicrobial activity (Chrzanowski et al., 2012; D'aes et al., 2010; Mann and Wozniak, 2012; Raaijmakers et al., 2010; Ron and Rosenberg, 2001).

Within a project aimed at examining atmospheric surfactants and characterizing their effects on cloud droplet formation, we focused on the biosurfactant-producing microorganisms present in atmospheric waters. Cloud water samples are collected at the Puy de Dôme station (France) belonging to the GAW (Global Atmosphere Watch) station network. A total of 480 bacterial and yeast strains were isolated and identified. This unique collection of microorganisms was screened to identify biosurfactant-producing microorganisms. The surface tension of crude extracts, comprising supernatants of the pure culture, was determined using the pendant drop technique (Hansen and Rødsrud, 1991). We observed a potential correlation between the composition of cloud water and the presence of biosurfactant-producing microorganisms. Finally, we discuss the potential impact of the production of biosurfactants by cloud microorganisms on atmospheric physicochemical processes.

\section{Materials and methods}

\subsection{Cloud sampling and physicochemical characterization of the cloud water samples}

Cloud water samples were collected using a cloud droplet impactor sterilized by autoclaving and installed on the summit of the Puy de Dôme (1465 m above sea level; $45^{\circ} 46^{\prime} 19^{\prime \prime} \mathrm{N}, 2^{\circ} 57^{\prime} 52^{\prime \prime} \mathrm{E}$; Massif Central). Non-precipitating and non-convective cloud samples were collected. The experiments were conducted using the 480 microbial strains collected during 39 cloud events from 2004 to 2014. The physicochemical content of the aqueous cloud samples was characterized (concentrations of organic acids, inorganic ions, and $\mathrm{pH}$; see Table $\mathrm{S} 1$ in the Supplement). Details about the sampling site, instrumentation, and procedures for cloud sampling, as well as the methods for the chemical analysis of cloud water samples, are provided in Deguillaume et al. (2014).

\subsection{Isolation and identification of microorganisms from cloud waters}

Triplicate volumes of $0.1 \mathrm{~mL}$ of cloud water were plated onto R2A agar growth medium (Reasoner and Geldreich, 1985; DIFCO ${ }^{\mathrm{TM}}$ ), and eventually onto R2A medium supplemented with $\mathrm{NaCl} 20 \mathrm{~g} \mathrm{~L}^{-1}$ and King's B (King et al., 1954), Sabouraud (DIFCO ${ }^{\mathrm{TM}}$ ) and TSA (Trypticase soy agar, $\mathrm{DIFCO}^{\mathrm{TM}}$ ) media. The plates were incubated at 17 or $5^{\circ} \mathrm{C}$ un- der dark, aerobic conditions until the appearance of colonies (typically 6 days at $17^{\circ} \mathrm{C}$ or 10 days at $5^{\circ} \mathrm{C}$ ) (Vaïtilingom et al., 2012). R2A medium is a poor medium with low nitrogen and carbon sources, initially developed to isolate microorganisms from tap water and is well adapted to cloud samples, which are also poor. The addition of $\mathrm{NaCl}$ to $\mathrm{R} 2 \mathrm{~A}$ favors the selection of marine microorganisms; King's B medium is selective for Pseudomonas strains, while Sabouraud medium is selective for yeast strains.

Representative colonies were selected based on colony morphology and pigment production. The isolates obtained in pure cultures $\left(\mathrm{R} 2 \mathrm{~A}, 17^{\circ} \mathrm{C}\right)$ were stored in $10 \%(v / v)$ glycerol at $-80^{\circ} \mathrm{C}$. The strains were identified by ribosomal RNA gene sequencing (16S or $26 \mathrm{~S}$ rRNA gene sequences for bacteria and yeasts, respectively). A complete description of the methods of identification is available in Vaïtilingom et al. (2012).

\subsection{Surface tension measurements}

Strains from the glycerol stocks were used to inoculate R2A broth in 96 deep-well plates $(500 \mu \mathrm{L}$ per well). The plates were incubated at $17^{\circ} \mathrm{C}$ under agitation for 5 days, followed by centrifugation $(3000 \mathrm{~g}$ for $20 \mathrm{~min}$ ). The supernatants were transferred into $1 \mathrm{~mL}$ microtubes and stored at $-30^{\circ} \mathrm{C}$ until subsequent surface tension measurements. The thawed samples were centrifuged (10480 $g$ for $3 \mathrm{~min}$ ) just prior to surface tension measurements.

All surface tension measurements were performed using the pendant drop method with an OCA 15Pro tensiometer (Data Physics, Germany). The camera analyzes the pendant drop profile of the crude extract. A dosing needle with a $1.65 \mathrm{~mm}$ outside diameter was used, producing drops of $12 \mu \mathrm{L}$. The software fits this latter measurement to the Young-Laplace equation and averages out surface tension from all measurements (Hansen and Rødsrud, 1991). The measurements were obtained at $295 \mathrm{~K}$ every second. The tensiometer was calibrated using Milli-Q water. The uncertainty of the instrument was $\pm 0.01 \mathrm{mN} \mathrm{m}^{-1}$. Each dynamic surface tension curve was measured three times for the most efficient biosurfactant-producing microorganisms, and the measurements displayed $\pm 10 \%$ variation. These dynamic surface tension measurements lasted until the equilibrium region is reached (maximum $30 \mathrm{~min}$; see below Sect. 3.2). Along with the surface tension, each measurement also provided realtime monitoring of the droplet volume, facilitating an assessment of the evaporation. No significant evaporation $(<5 \%)$ was observed during the experiments (Fig. 2).

\section{Results}

\subsection{Identification of cloud microbial isolates}

The identification of the 480 strains (bacteria and yeasts) collected during the 39 cloud events at the Puy de Dôme station, 


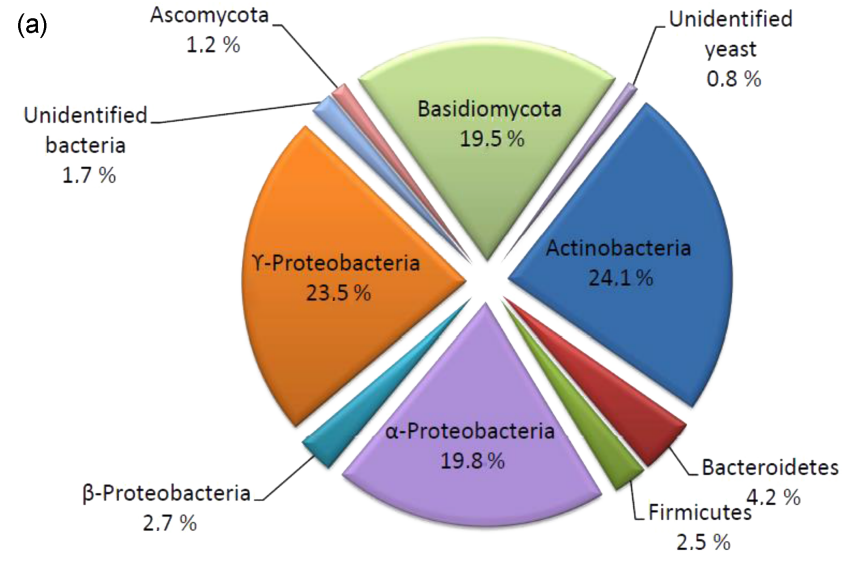

(b)

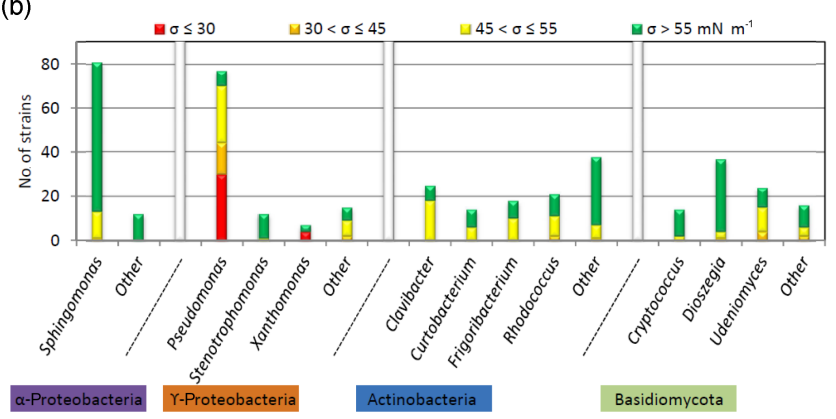

Figure 1. (a) Phylum distribution of the 480 strains examined for biosurfactant production. (b) Genus distribution of the most representative strains (85\%: $\alpha$ - and $\Upsilon$-Proteobacteria, Actinobacteria, and Basidiomycota). The four categories of surface tension $(\sigma \leq 30$, $30<\sigma \leq 45,45<\sigma \leq 55$, and $\sigma>55 \mathrm{mN} \mathrm{m}^{-1}$ ) are indicated in red, orange, yellow, and green, respectively.

together with the values of surface tension obtained from their crude supernatants after 5 days of culture in R2A broth, is described in the Supplement (Table S2).

Figure 1a shows the distribution of the different phyla or classes of these microbial isolates. Three phyla of microorganisms were dominant - Proteobacteria $(\alpha, \beta$, and $\Upsilon$-Proteobacteria), Actinobacteria, and Basidiomycota - accounting for $89.6 \%$ of the collection, while $2.5 \%$ of the microbial strains remain unidentified.

In detail (Fig. 1b), the phylum of Proteobacteria was predominant (220 isolates, $45.8 \%$ ), particularly $\alpha$ - and $\Upsilon$ Proteobacteria (95 and 112 isolates, 19.8 and $23.3 \%$, respectively). In these latter two classes, the most recurrent strains belonged to the genera Sphingomonas (83 isolates) and Pseudomonas (78 isolates), respectively. $\beta$-Proteobacteria represent only $2.7 \%$ of the total. The phylum Actinobacteria (116 isolates, $24.2 \%$ ) primarily contained strains from the genera Clavibacter (25 isolates), Curtobacterium (14 isolates), Frigoribacterium (18 isolates), and Rhodococcus (21 isolates). Notably, the phylum Actinobacteria presents a much greater diversity of genera compared with the other phyla, centered on one dominant genus. Among the bacterial strains, the phyla Bacteroidetes and Firmicutes were also represented, but to a lesser extent ( 20 and 12 isolates, respectively, 4.2 and $2.5 \%$ ).

Concerning yeasts, the major group belonged to the phylum Basidiomycota (94 isolates, 19.6\%), primarily containing strains from the genera Cryptococcus (14 isolates), Dioszegia (39 isolates), and Udeniomyces (25 isolates). The phylum Ascomycota was also present but with only 6 isolates $(1.2 \%)$.

Globally, the phylogeny of the isolated strains examined in the present study is consistent with the previously published phylogeny of the strains isolated from the same sampling sites, except for the genus Bacillus, which was much less abundant in the selected cloud events (Vaitilingom et al., 2012). Notably, many strains originated from the phyllosphere, consistent with the predominance of the phylum Proteobacteria. These 480 strains therefore constitute a unique collection of cloud microorganisms, representative of a cloud community that can be tested for biosurfactant production.

\subsection{Screening for biosurfactant-producing microorganisms}

Figure 2 shows the time profile of the surface tension measurements performed on the culture supernatants of four selected microbial strains. As a reference, the surface tension obtained from R2A medium, which served as the culture medium, is also presented. In this case, the observed surface tension $\left(63 \mathrm{mN} \mathrm{m}^{-1}\right)$ remained close to the value of pure water $\left(72.8 \mathrm{mN} \mathrm{m}^{-1}\right)$. As expected, a noticeable reduction of the surface tension values was observed when the microorganisms produced biosurfactants in the culture medium. This phenomenon is time-dependent, and the time profiles were dependent on the studied strain. These profiles were consistent with those obtained from atmospheric aerosol by Nozière et al. (2014) and are typical of a surface tension dynamic (Hua and Rosen, 1991). Indeed, three distinct kinetic regimes follow each other during the equilibration process: first, a rapid decline of the R2A value to $\sigma_{0}$ occurs, which happens too rapidly to record $(<0.1 \mathrm{~s})$; this is followed by the meso-equilibrium phase, during which the surface tension decreases to $\sigma_{\mathrm{m}}$; then, the appearance of the equilibrium region occurs, where the minimum, $\sigma_{\mathrm{eq}}$, is reached. This region corresponds to the saturation of the surface $\left(\Gamma_{\infty}\right)$ with surfactant molecules. Hereafter, the surface tension measurements $(\sigma)$ are referred to as $\sigma_{\text {eq }}$.

Monitoring the surface tension over time revealed that the equilibration time (apparent diffusion coefficient) in the pendant drops varied from a few seconds to $30 \mathrm{~min}$, likely depending on the concentration and chemical structure of the expressed biosurfactants, which affect molecular interactions and/or diffusion. For example, from the supernatant of the strains 59b03 and 14b02, two Pseudomonas strains $(\Upsilon$ - 


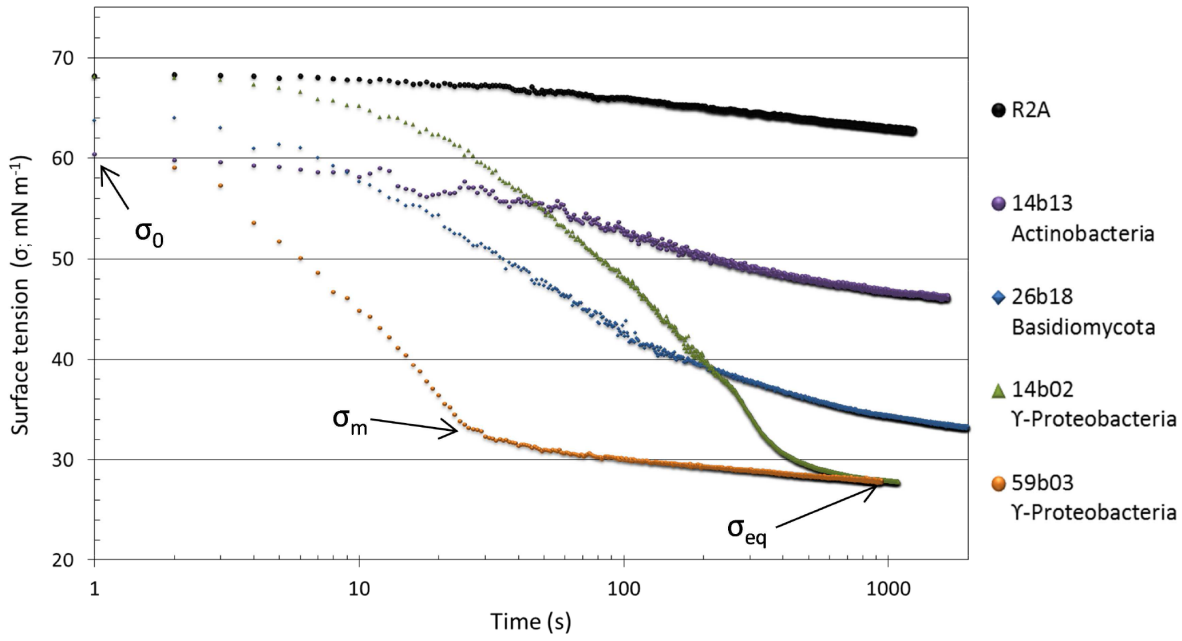

Figure 2. Time profile of the surface tension measurements. In black, R2A broth medium. In purple, strain $14 \mathrm{~b} 13$ (Frigoribacterium sp., Actinobacteria). In blue, strain $26 \mathrm{~b} 18$ (Cryptococcus sp., Basidiomycota). In green, strain 14b02 (Pseudomonas sp., $\Upsilon$-Proteobacteria). In orange, strain $59 \mathrm{~b} 03$ (Pseudomonas syringae, $\Upsilon$-Proteobacteria). Initial surface tension $\left(\sigma_{0}\right)$. Surface tension in the meso-equilibrium $\left(\sigma_{\mathrm{m}}\right)$ and equilibrium $\left(\sigma_{\mathrm{eq}}\right)$ phases.

Proteobacteria), the measured equilibrium surface tensions $\left(\sigma_{\mathrm{eq}}\right)$ were close (below $28 \mathrm{mN} \mathrm{m}^{-1}$ ), while the time profiles were much more different, and the equilibration stage occurred at approximately 2 and $10 \mathrm{~min}$, respectively.

The 480 strains tested for biosurfactant production (see Supplement Table S2) were differentiated into four main categories according to the measured surface tension $(\sigma \leq$ $30,30<\sigma \leq 45,45<\sigma \leq 55$, and $\sigma>55 \mathrm{mN} \mathrm{m}^{-1}$, Figs. $1 \mathrm{~b}$ and 3). The first category $\left(\sigma \leq 30 \mathrm{mN} \mathrm{m}^{-1}\right)$ is rare among man-made surfactants and is typical of surfactants of biological origin (Christofi and Ivshina, 2002). In this collection, we observed 34 strains $(7 \%)$ that reduce the surface tension of the $\mathrm{R} 2 \mathrm{~A}$ broth below $30 \mathrm{mN} \mathrm{m}^{-1}$. These strains exclusively belonged to the genera Pseudomonas and Xanthomonas ( $\Upsilon$-Proteobacteria, Fig. 1b). The second category corresponded to surface tension values between 30 and $45 \mathrm{mN} \mathrm{m}^{-1}$. The $45 \mathrm{mN} \mathrm{m}^{-1}$ limit is often considered the threshold in terms of the surface tension decrease originating from HULIS (humic-like substances) (Kiss et al., 2005; Taraniuk et al., 2007). We observed only 30 strains $(6 \%)$ in this second category. In summary, from the first two categories $\left(\sigma \leq 45 \mathrm{mN} \mathrm{m}^{-1}\right)$, although new phyla were observed in the second category, the phylum distribution of the most efficient biosurfactant-producing microorganisms remains largely dominated by $\Upsilon$-Proteobacteria ( $78 \%$ of all strains) and more moderately by Basidiomycota (11\%) (Fig. 3). Notably, the two other major taxa of all studied strains, Actinobacteria and $\alpha$-Proteobacteria, almost completely disappear in these categories. The third and fourth categories $\left(45<\sigma \leq 55\right.$ and $\left.\sigma>55 \mathrm{mN} \mathrm{m}^{-1}\right)$ represented 28 and $59 \%$ of the collection, respectively. The $55 \mathrm{mN} \mathrm{m}^{-1}$ limit is relatively arbitrary but approximates the first surface tension values measured on the aerosol filter samples (Baduel et al., 2012; Capel et al., 1990; Decesari et al., 2005; Facchini et al., 1999, 2000; Hitzenberger et al., 2002; Mircea et al., 2005). Remarkably, Pseudomonas ( $\Upsilon$-Proteobacteria) and Sphingomonas ( $\alpha$-Proteobacteria), the most frequently observed genera in the clouds (Vaiitilingom et al., 2012), showed completely different behaviors: Pseudomonas provide the most active biosurfactant-producing microorganisms, while almost all Sphingomonas are not efficient for the production of biosurfactants.

\subsection{Potential impact of the chemical composition of the clouds on biosurfactant production}

In the present study, the screened microbial strains were isolated from 39 cloud events presenting different profiles. Information on the cloud chemical composition and the physicochemical parameters measured at the Puy de Dôme station and described in Deguillaume et al. (2014) is provided on the website of the Observatory of Earth Physics in ClermontFerrand (http://wwwobs.univ-bpclermont.fr/SO/beam/data. php). The main parameters - including $\mathrm{pH}, \mathrm{SO}_{4}^{2-}, \mathrm{NO}_{3}^{-}$, $\mathrm{Cl}^{-}$, acetate, formate, oxalate, succinate, malonate, $\mathrm{Na}^{+}$, $\mathrm{NH}_{4}^{+}, \mathrm{Mg}^{2+}, \mathrm{K}^{+}$, and $\mathrm{Ca}^{2+}-$ are summarized in the Supplement (Table S1). These physicochemical parameters were used for the ACP analysis as described in Deguillaume et al. (2014). The ACP generated four different types of clouds, classified as "highly marine", "marine", "continental", and "polluted". Typically, the more "polluted" clouds have a lower $\mathrm{pH}$ and higher concentrations of $\mathrm{NH}_{4}^{+}, \mathrm{NO}_{3}^{-}$, and $\mathrm{SO}_{4}^{2-}$. The more "marine" clouds have a higher concentration of $\mathrm{NaCl}$. The 39 cloud events were divided into 2 "highly marine", 26 "marine", 8 "continental", and 3 "polluted" clouds (Table S1). 


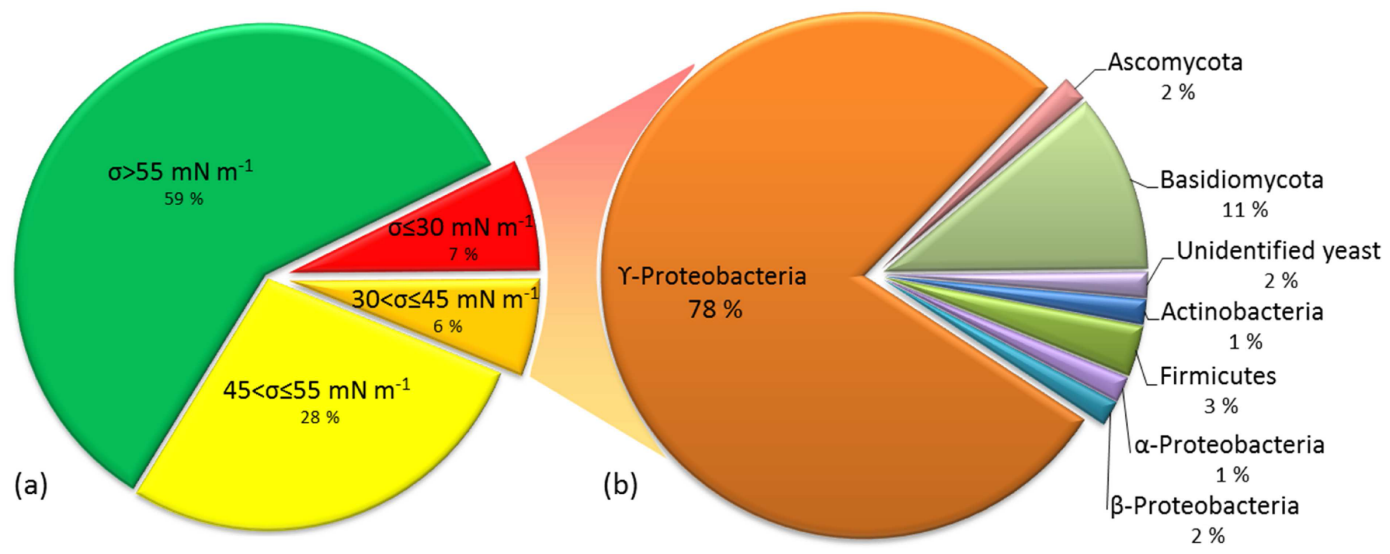

Figure 3. (a) Surface tension $(\sigma)$ distribution of the 480 strains examined for biosurfactant production and (b) the phylum distribution for the most efficient biosurfactant-producing microorganisms $\left(\sigma \leq 45 \mathrm{mN} \mathrm{m}^{-1}\right)$.
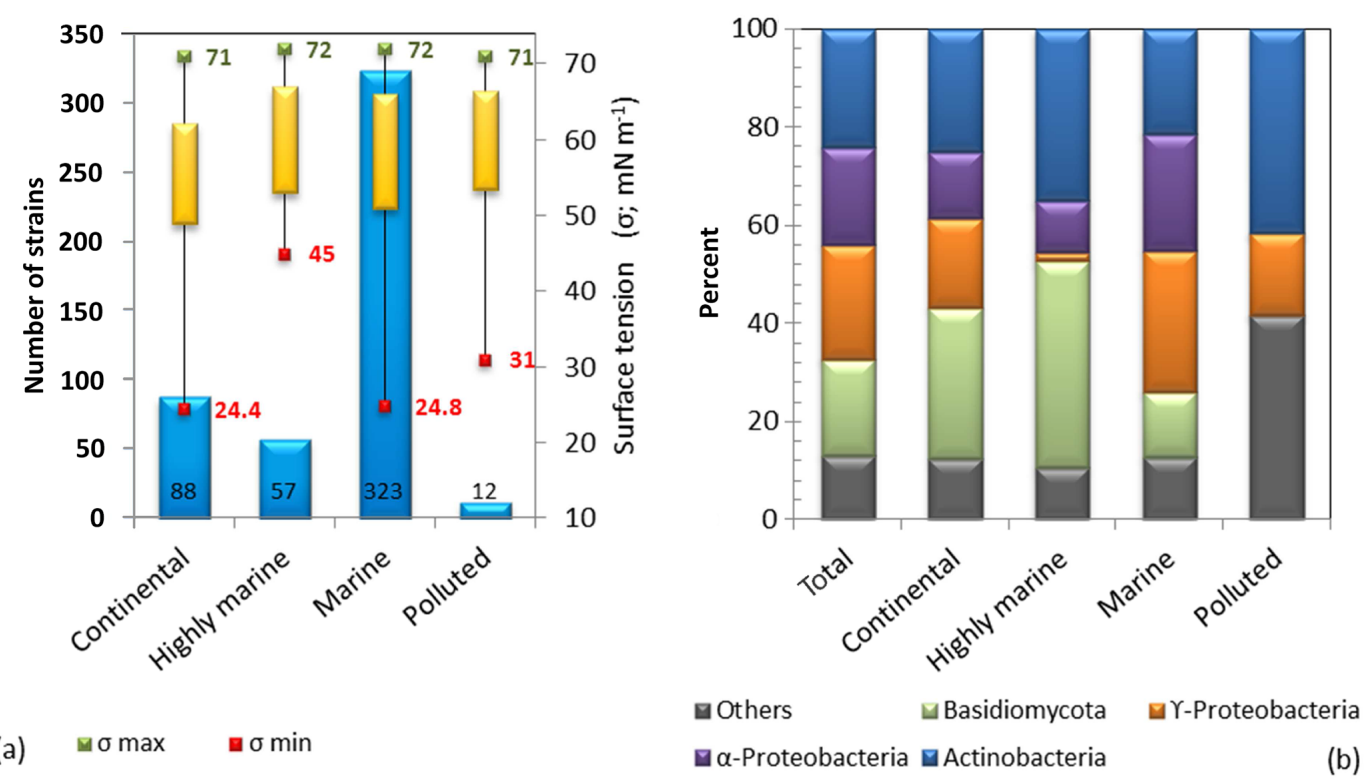

Figure 4. (a) Surface tension $(\sigma)$ distribution of the 480 strains examined for biosurfactant production according to the physicochemical characteristics of cloud waters (continental, highly marine, marine, and polluted). Highlighted in blue, the number of tested strains. Box and whisker plots are shown with the minimal (red) and maximal (green) surface tensions. The yellow boxes represent the 25th and 75th percentiles of the measurements. (b) Phylum distribution according to the physicochemical characteristics of the cloud waters (total, continental, highly marine, marine, and polluted).

Figure 4 a shows the distribution of the surface tension values $(\sigma)$ measured from the 480 strains examined for biosurfactant production according to the cloud water chemical composition (marine, highly marine, continental or polluted). A comparison of the distribution of the phyla of the strains in the same cloud events is presented in Fig. 4b. The samples from marine clouds constitute the majority of this collection (323/480 strains). We observed a difference between the surface tension values from continental and highly marine strains (medians: 56 and $61 \mathrm{mN} \mathrm{m}^{-1}$, respectively). Highly marine clouds are characterized by the highest min- imal surface tension $\left(45 \mathrm{mN} \mathrm{m}^{-1}\right.$, Fig. $\left.4 a\right)$, consistent with the almost complete absence of $\Upsilon$-Proteobacteria, which are the most efficient biosurfactant-producing microorganisms $\left(\sigma \leq 45 \mathrm{mN} \mathrm{m}^{-1}\right)$ (1/57 isolates; see Fig. $\left.4 \mathrm{~b}\right)$. These observations were based on 39 cloud events with 480 different strains, representing, to the best of our knowledge, the largest cloud sample data set studied; this data set is representative of cloud sampling over more than 10 years at the Puy de Dôme station. Although it remains difficult to generate statistics on samples with such intra- and inter-sample variations, 
these results provide a general tendency that could be reinforced and confirmed with more data in the future.

\section{Discussion and conclusion}

The study of biosurfactant production in the environment has primarily focused on microorganisms isolated from soils, rhizospheres, and the phyllosphere or from the marine environment (Bodour et al., 2003; Jackson et al., 2015; Raaijmakers et al., 2010; Satpute et al., 2010). Concerning atmospheric waters, Ahern et al. (2007) reported the presence of biosurfactant-producing bacteria in the air, studying 100 strains isolated from four rain and cloud samples. Here, we investigated 480 strains isolated from 39 different cloud events. When we consider that these strains typically produce biosurfactants when the measured surface tension $\left(\sigma_{\mathrm{eq}}\right)$ is less than $55 \mathrm{mN} \mathrm{m}^{-1}, 41 \%$ of the tested strains were active, with $7 \%$ being extremely active $\left(\sigma<30 \mathrm{mN} \mathrm{m}^{-1}\right)$. Although the methods used to evaluate biosurfactant production were different, this result is consistent with that of Ahern et al. (2007), who reported $55 \%$ active strains in rain and cloud samples. In the present study, we showed that, under laboratory conditions, the most efficient biosurfactantproducing microorganisms $\left(\sigma<45 \mathrm{mN} \mathrm{m}^{-1}\right)$ belonged to a limited number of bacterial genera (Pseudomonas and Xanthomonas) from the $\Upsilon$-Proteobacteria class $(78 \%)$ and a yeast genus (Udeniomyces) from the Basidiomycota phylum (11\%). Some Bacillus strains from the Firmicutes phylum were also active but represented a small fraction (3\%) of the total population of the cloud collection examined in the present study. Strains from the Actinobacteria phylum were primarily present in the group with moderate biosurfactant production $\left(45<\sigma<55 \mathrm{mN} \mathrm{m}^{-1}\right)$. In previous studies, Pseudomonas ( $\Upsilon$-Proteobacteria) and Bacillus (Firmicutes) have been reported as high-biosurfactant-producing microorganisms; Acinetobacter ( $\alpha$-Proteobacteria) has also been frequently reported (Desai and Banat, 1997; Rosenberg and Ron, 1999). For yeasts, the major high-biosurfactantproducing genera include Candida and Torulopsis from the phylum Ascomycota (Desai and Banat, 1997; Karanth et al., 1999; Rosenberg and Ron, 1999). In the present study, Pseudomonas strains were clearly the dominant group and the most active biosurfactant-producing microorganisms, whereas the genus Acinetobacter was absent. This result is highly consistent with studies performed on environmental samples, such as soils (Bodour et al., 2003), plants (D'aes et al., 2010; Raaijmakers et al., 2010), and seawater (Cai et al., 2015), and in atmospheric water (Ahern et al., 2007).

Notably, the genus Pseudomonas is commonly detected in the phyllosphere, the main source of primary bioaerosols (Amato et al., 2007b; Morris et al., 2014; Vaitilingom et al., 2012). Interestingly, biosurfactants play a specific role in the interactions between plants and Pseudomonas (D'aes et al., 2010; Raaijmakers et al., 2010). Biosurfactants present versatile functions, including interactions with other organisms (such as antibiotic activity) and modifications of the leaf-surface properties. These surface modifications enable cell mobility, biofilm formation, and the colonization of the leaves by these bacteria. Particularly, rhamnolipids are involved in different processes of biofilm formation; the final step involves the release of the planktonic daughter population (Mann and Wozniak, 2012). This production of biosurfactants could therefore be important for the formation of biofilms on leaf surfaces, facilitating the aerosolization and dispersion of Pseudomonas strains in the air.

This aerosolization of Pseudomonas strains could explain the correlation observed between the clouds composition and the distribution of biosurfactant-producing microorganisms observed in the present study. It is clear that microbial isolates from highly marine clouds, significantly impacted by the ocean source (an almost total absence of $\Upsilon$ Proteobacteria; see Fig. 4b), are lower biosurfactant producers than microorganisms isolated from continental clouds. Continental clouds, traveling over vegetated zones, thus contain more Pseudomonas strains. More generally, the correlation between the different origins of the air masses and the production of biosurfactants by cloud microorganisms could be explained by the significant differences in the vegetation of France. For example, French regions characterized by uniform monocultures (Ministère de l'Agriculture, de l'Agroalimentaire et de la Forêt, 2014) could be extremely favorable to plant pathogens, such as Pseudomonas syringae (McDonald and Linde, 2002).

The occurrence of biosurfactants has recently been shown in atmospheric aerosols (Baduel et al., 2012; Ekström et al., 2010; Nozière et al., 2014). Indeed, the presence of biosurfactants in the atmosphere could result from different mechanisms. First, these aerosols could be directly produced by microorganisms in the clouds. This idea is relevant considering that microorganisms are metabolically active in clouds and can survive under atmospheric conditions (Joly et al., 2015, and references therein). Indeed, microbial metabolic activity has been demonstrated by measurements of the ATP (adenosine 5'triphosphate) content (Amato et al., 2005, 2007a; Vaittilingom et al., 2012, 2013) and by the uptake of the dye CTC (5-cyano-2,3-ditolyl tetrazolium chloride) directly in situ in cloud water samples (Hill et al., 2007). This activity has even been demonstrated at low temperatures (Sattler et al., 2001). In addition, these microorganisms also survive and resist atmospheric stresses, including evaporationcondensation cycles; freeze-thaw cycles; and exposure to oxidants, solar light, and cold temperature (Delort et al., 2010; Joly et al., 2015). Biosurfactants can also be produced in extreme environments, such as deep sea or Arctic soil (Jackson et al., 2015; Janek et al., 2013). Under laboratory conditions, the microorganisms produced biosurfactants within the first $24 \mathrm{~h}$, even in poor nutritive medium (R2A). As the residence time of microorganisms in the atmosphere was modeled between 2 and 10 days (Burrows et al., 2009), these metaboli- 
cally active microorganisms could thus synthesize biosurfactants in the clouds. A second and obvious pathway for the incorporation of biosurfactants in the atmosphere is associated with the presence of these molecules at the surface of the microorganisms. Biosurfactants can therefore be carried together with the microorganisms when aerosolized or in a biofilm existing on dust or leaf particles. Moreover, biosurfactants could be directly emitted into the atmosphere as biogenic aerosols, particularly biosurfactants of marine origin, which can be emitted in sea sprays during bubbling and wave breaking processes (Blanchard, 1989; Elliott et al., 2014).

The presence of biosurfactants might have implications for atmospheric processes. First, these molecules could impact atmospheric chemistry. For example, the in situ biosynthesis of biosurfactants by microorganisms in clouds could be considered as the production of secondary organic aerosols, thus modifying the global carbon balance in the water phase. The presence of biosurfactants (aerosolized from the Earth's surface or produced in situ) at the surface of cloud droplets could also change the precise picture of the mass transfer between the gas and water phases of clouds. Organic surface films can provide barriers against transportation across the air-particle interface, inhibiting the uptake of water- and gas-phase species. These organic films can be an auspicious medium for solubilizing gas-phase organic species, perhaps reflecting the observed non-Henry's law concentration of organics in field samples (Barnes, 1986; Davies et al., 2013; Lo and Lee, 1996; Park et al., 2009; Renard et al., 2014). The chemical characterization and the study of the reactivity of these organic layers will be of special interest to further understand cloud chemistry.

Second, biosurfactants could affect atmospheric microphysics by modifying CCN activation. Owing to their exceptional scope in reducing surface tension, biosurfactants per se, whether present on aerosols or associated at the microorganism surface, are thus likely to enhance the propensity of these aerosols to form clouds, as the activation of particles into cloud droplets depends on surface tension according to Köhler's theory (Köhler, 1936). This topic has been controversial, but recently, Nozière et al. (2014) showed that the total surfactant fraction of atmospheric particles is much more surface-active $\left(\sigma \leq 30 \mathrm{mN} \mathrm{m}^{-1}\right)$ than HULIS. These authors demonstrated that the equilibration time of biosurfactants might hinder the measurement of such an effect when using classical instruments, such as a hygroscopic tandem differential mobility analyzer or a $\mathrm{CCN}$ counter. Upon further examination of the results obtained in the present study, it is reasonable to consider that biosurfactant partitioning in macroscopic pendant droplets might decrease the surface tension values relative to atmospheric conditions. Indeed, in a microscopic $\left(D_{\text {wet }} \approx 1 \mu \mathrm{m}\right)$ droplet, the partitioning impact could be insignificant owing to a surface area to volume ratio several orders of magnitude higher (Prisle et al., 2012; Sorjamaa et al., 2004). Nevertheless, the lower the radius of the droplet or the higher the surface to volume ratio, the higher the bacte- ria concentration (Aller et al., 2005; Hejkal et al., 1980) and the higher the WSOC concentration (Ervens and Volkamer, 2010). By dividing the surfactant concentration in the atmosphere $\left(\sim 10^{-12}-10^{-9} \mathrm{~mol} \mathrm{~m}^{-3}\right.$ in Olkowska et al., 2014) by the liquid water content of wet aerosol $\left(\sim 10^{-6}-10^{-5} \mathrm{~g} \mathrm{~m}^{-3}\right.$ in Ervens and Volkamer, 2010), we obtained a significant concentration in the range of $\sim \mathrm{mM}$. A recent study (Gérard et al., 2016) reported concentrations above the typical CMC. Thus, Ruehl et al. (2012) presented strong evidence that surface tension reduction can occur in microscopic droplets, and even more in wet aerosol, provided that the particles predominantly (i.e., $80 \%$ ) comprise surfactants.

The influence of biological surfactants on the prediction of particle cloud activation and indirect aerosol climate effects should be implemented in models. Indeed, if the effects of organic surfactants (particularly carboxylic acids) on the surface tension of activating droplets is considered in parameterizations (Abdul-Razzak and Ghan, 2004), then recent studies have shown that the surface partitioning of organic molecules to a microscopic aqueous droplet interface should also be considered in models (Noziere, 2016; Prisle et al., 2012; Ruehl et al., 2016).

Moreover, because Pseudomonas strains are the most efficient biosurfactant-producing bacteria and are dominant in clouds and rain (the present study and Ahern et al., 2007), questions arise about the potential role of biosurfactants in the cycle of Pseudomonas in the atmosphere. Indeed, biosurfactants facilitate the aerosolization of these strains from leaf surfaces and favor the formation of cloud droplets through the modification of the surface properties of the cells. Moreover, most of these strains belong to Pseudomonas syringae species, which are ice nuclei active and can induce precipitation back to the ground. Thus, biosurfactants should be integrated into the life history of Pseudomonas syringae and its relationship to the water cycle (Morris et al., 2008, 2014).

In conclusion, the results of the present study showed that the microbial strains isolated from cloud waters produce strong biosurfactants under laboratory conditions. The major and most active producers belong to the genus Pseudomonas, which is prevalent in cloud water and typically originates from the phyllosphere. Although the presence of surfactants has been shown on aerosols (Nozière et al., 2014), it has not yet been demonstrated in clouds, and the structure of these compounds has not been established. The biosurfactants overproduced by the best producers in the present study will be isolated to analyze their chemical structure. In parallel, the biosurfactants from cloud aerosols and rain samples will also be extracted, and their structural fingerprints will be analyzed and compared with the signatures of microbial surfactants isolated from clouds. These comparisons should provide evidence of the microbial origin of the surfactants present on aerosols. Studying such biosurfactants in the atmosphere is of special interest for the chemical characterization and reactivity of organic layers, and the characterization of their impact on mass transfer and water uptake. The 
activation of aerosols containing organic matter is a major topic directly associated with the climatic effects of aerosolcloud interactions. A small change in the droplet population could affect cloud albedo and the formation of precipitation (Li et al., 2011; Rodhe, 1999). Hence, there is a need to enhance our knowledge about biosurfactants, focusing on the extent of their impact on human health and the global climate (Brimblecombe and Latif, 2004).

\section{The Supplement related to this article is available online at doi:10.5194/acp-16-12347-2016-supplement.}

Acknowledgements. This work was funded by the French-US program SONATA (ANR-NSF) and the French-Slovak program Stefanik (PHC). Cloud sampling was possible thanks to the staff of the Observatoire de Physique du Globe de Clermont-Ferrand. The authors would like to thank Magali Abrantes for her technical assistance.

Edited by: V. Faye McNeill

Reviewed by: two anonymous referees

\section{References}

Abdul-Razzak, H. and Ghan, S. J.: Parameterization of the influence of organic surfactants on aerosol activation, J. Geophys. Res.Atmos., 109, D03205, doi:10.1029/2003JD004043, 2004.

Ahern, H. E., Walsh, K. A., Hill, T. C. J., and Moffett, B. F.: Fluorescent pseudomonads isolated from Hebridean cloud and rain water produce biosurfactants but do not cause ice nucleation, Biogeosciences, 4, 115-124, doi:10.5194/bg-4-115-2007, 2007.

Aller, J. Y., Kuznetsova, M. R., Jahns, C. J., and Kemp, P. F.: The sea surface microlayer as a source of viral and bacterial enrichment in marine aerosols, J. Aerosol Sci., 36, 801-812, doi:10.1016/j.jaerosci.2004.10.012, 2005.

Amato, P., Ménager, M., Sancelme, M., Laj, P., Mailhot, G., and Delort, A.-M.: Microbial population in cloud water at the Puy de Dôme: Implications for the chemistry of clouds, Atmos. Environ., 39, 4143-4153, doi:10.1016/j.atmosenv.2005.04.002, 2005.

Amato, P., Parazols, M., Sancelme, M., Mailhot, G., Laj, P., and Delort, A.-M.: An important oceanic source of micro-organisms for cloud water at the Puy de Dôme (France), Atmos. Environ., 41, 8253-8263, doi:10.1016/j.atmosenv.2007.06.022, 2007a.

Amato, P., Hennebelle, R., Magand, O., Sancelme, M., Delort, A.-M., Barbante, C., Boutron, C., and Ferrari, C.: Bacterial characterization of the snow cover at Spitzberg, Svalbard, FEMS Microbiol. Ecol., 59, 255-264, doi:10.1111/j.15746941.2006.00198.x, 2007b.

Aumann, E. and Tabazadeh, A.: Rate of organic film formation and oxidation on aqueous drops, J. Geophys. Res., 113, 329-337, doi:10.1029/2007JD009738, 2008.

Aumann, E., Hildemann, L. M., and Tabazadeh, A.: Measuring and modeling the composition and temperature-dependence of surface tension for organic solutions, Atmos. Environ., 44, 329-337, doi:10.1016/j.atmosenv.2009.10.033, 2010.
Baduel, C., Nozière, B., and Jaffrezo, J.-L.: Summer/winter variability of the surfactants in aerosols from Grenoble, France, Atmos. Environ., 47, 413-420, doi:10.1016/j.atmosenv.2011.10.040, 2012.

Banat, I. M., Franzetti, A., Gandolfi, I., Bestetti, G., Martinotti, M. G., Fracchia, L., Smyth, T. J., and Marchant, R.: Microbial biosurfactants production, applications and future potential, Appl. Microbiol. Biot., 87, 427-444, doi:10.1007/s00253-010-2589-0, 2010.

Barnes, G. T.: The effects of monolayers on the evaporation of liquids, Adv. Colloid Interface Sci., 25, 89-200, doi:10.1016/00018686(86)80004-5, 1986.

Bertram, A. K., Ivanov, A. V., Hunter, M., Molina, L. T., and Molina, M. J.: The Reaction Probability of $\mathrm{OH}$ on Organic Surfaces of Tropospheric Interest, J. Phys. Chem. A, 105, 94159421, doi:10.1021/jp0114034, 2001.

Blanchard, D. C.: The ejection of drops from the sea and their enrichment with bacteria and other materials: a review, Estuaries Coasts, 12, 127-137, 1989.

Bodour, A. A., Drees, K. P., and Maier, R. M.: Distribution of Biosurfactant-Producing Bacteria in Undisturbed and Contaminated Arid Southwestern Soils, Appl. Environ. Microbiol., 69, 3280-3287, doi:10.1128/AEM.69.6.3280-3287.2003, 2003.

Boucher, O., Randall, D., Artaxo, P., Bretherton, C., Feingold, G., Forster, P., Kerminen, V.-M., Kondo, Y., Liao, H., Lohmann, U., and others: Clouds and aerosols, in Climate change 2013: the physical science basis. Contribution of Working Group I to the Fifth Assessment Report of the Intergovernmental Panel on Climate Change, 571-657, Cambridge University Press, 2013.

Brimblecombe, P. and Latif, M. T.: Rediscovering Atmospheric Surfactants, Environ. Chem.-Env. CHEM, 1, 11-12, doi:10.1071/EN04044, 2004.

Burrows, S. M., Elbert, W., Lawrence, M. G., and Pöschl, U.: Bacteria in the global atmosphere - Part 1: Review and synthesis of literature data for different ecosystems, Atmos. Chem. Phys., 9, 9263-9280, doi:10.5194/acp-9-9263-2009, 2009.

Cai, Q., Zhang, B., Chen, B., Song, X., Zhu, Z., and Cao, T.: Screening of biosurfactant-producing bacteria from offshore oil and gas platforms in North Atlantic Canada, Environ. Monit. Assess. 187, 1-12, doi:10.1007/s10661-015-4490-x, 2015.

Capel, P. D., Gunde, R., Zuercher, F., and Giger, W.: Carbon speciation and surface tension of fog, Environ. Sci. Technol., 24, 722-727, doi:10.1021/es00075a017, 1990.

Chakraborty, P. and Zachariah, M. R.: On the Structure of Organic Coated Water Droplets: From Net Water Attractors to Oily Surfaces, J. Geophys. Res., 116, D21205, doi:10.1029/2011JD015961, 2011.

Christofi, N. and Ivshina, I. B.: Microbial surfactants and their use in field studies of soil remediation, J. Appl. Microbiol., 93, 915929, doi:10.1046/j.1365-2672.2002.01774.x, 2002.

Chrzanowski, Ł., Ławniczak, Ł., and Czaczyk, K.: Why do microorganisms produce rhamnolipids?, World J. Microbiol. Biotechnol., 28, 401-419, doi:10.1007/s11274-011-0854-8, 2012.

Clifford, D., Bartels-Rausch, T., and Donaldson, D. J.: Suppression of aqueous surface hydrolysis by monolayers of short chain organic amphiphiles, Phys. Chem. Chem. Phys., 9, 1362-1369, doi:10.1039/b617079j, 2007.

D'aes, J., De Maeyer, K., Pauwelyn, E., and Höfte, M.: Biosurfactants in plant-Pseudomonas interactions and their im- 
portance to biocontrol, Environ. Microbiol. Rep., 2, 359-372, doi:10.1111/j.1758-2229.2009.00104.x, 2010.

Davies, J. F., Miles, R. E. H., Haddrell, A. E., and Reid, J. P.: Influence of organic films on the evaporation and condensation of water in aerosol, P. Natl. Acad. Sci. USA, 110, 8807-8812, doi:10.1073/pnas.1305277110, 2013.

Decesari, S., Facchini, M. C., Matta, E., Lettini, F., Mircea, M., Fuzzi, S., Tagliavini, E., and Putaud, J.-P.: Chemical features and seasonal variation of fine aerosol water-soluble organic compounds in the Po Valley, Italy, Atmos. Environ., 35, 3691-3699, doi:10.1016/S1352-2310(00)00509-4, 2001.

Decesari, S., Facchini, M. C., Mircea, M., Cavalli, F., and Fuzzi, S.: Solubility properties of surfactants in atmospheric aerosol and cloud/fog water samples, J. Geophys. Res.-Atmos., 108, 4685, doi:10.1029/2003JD003566, 2003.

Decesari, S., Facchini, M. C., Fuzzi, S., McFiggans, G. B., Coe, H., and Bower, K. N.: The water-soluble organic component of size-segregated aerosol, cloud water and wet depositions from Jeju Island during ACE-Asia, Atmos. Environ., 39, 211-222, doi:10.1016/j.atmosenv.2004.09.049, 2005.

Deguillaume, L., Charbouillot, T., Joly, M., Vaïtilingom, M., Parazols, M., Marinoni, A., Amato, P., Delort, A.-M., Vinatier, V., Flossmann, A., Chaumerliac, N., Pichon, J. M., Houdier, S., Laj, P., Sellegri, K., Colomb, A., Brigante, M., and Mailhot, G.: Classification of clouds sampled at the puy de Dôme (France) based on $10 \mathrm{yr}$ of monitoring of their physicochemical properties, Atmos. Chem. Phys., 14, 1485-1506, doi:10.5194/acp-14-14852014, 2014.

Delort, A.-M., Vaïtilingom, M., Amato, P., Sancelme, M., Parazols, M., Mailhot, G., Laj, P., and Deguillaume, L.: A short overview of the microbial population in clouds: Potential roles in atmospheric chemistry and nucleation processes, Atmos. Res., 98, 249-260, doi:10.1016/j.atmosres.2010.07.004, 2010.

Desai, J. D. and Banat, I. M.: Microbial production of surfactants and their commercial potential., Microbiol. Mol. Biol. R., 61, 47-64, 1997.

Dinar, E., Taraniuk, I., Graber, E. R., Katsman, S., Moise, T., Anttila, T., Mentel, T. F., and Rudich, Y.: Cloud Condensation Nuclei properties of model and atmospheric HULIS, Atmos. Chem. Phys., 6, 2465-2482, doi:10.5194/acp-6-2465-2006, 2006.

Ekström, S., Nozière, B., Hultberg, M., Alsberg, T., Magnér, J., Nilsson, E. D., and Artaxo, P.: A possible role of ground-based microorganisms on cloud formation in the atmosphere, Biogeosciences, 7, 387-394, doi:10.5194/bg-7-387-2010, 2010.

Elliott, S., Burrows, S. M., Deal, C., Liu, X., Long, M., Ogunro, O., Russell, L. M., and Wingenter, O.: Prospects for simulating macromolecular surfactant chemistry at the ocean-atmosphere boundary, Environ. Res. Lett., 9, 64012, doi:10.1088/17489326/9/6/064012, 2014.

Ellison, G. B., Tuck, A. F., and Vaida, V.: Atmospheric processing of organic aerosols, J. Geophys. Res.-Atmos., 104, 1163311641, doi:10.1029/1999JD900073, 1999.

Ervens, B. and Volkamer, R.: Glyoxal processing by aerosol multiphase chemistry: towards a kinetic modeling framework of secondary organic aerosol formation in aqueous particles, Atmos. Chem. Phys., 10, 8219-8244, doi:10.5194/acp-10-8219-2010, 2010 .
Facchini, M. C., Mircea, M., Fuzzi, S., and Charlson, R. J.: Cloud albedo enhancement by surface-active organic solutes in growing droplets, Nature, 401, 257-259, doi:10.1038/45758, 1999.

Facchini, M. C., Decesari, S., Mircea, M., Fuzzi, S., and Loglio, G.: Surface tension of atmospheric wet aerosol and cloud/fog droplets in relation to their organic carbon content and chemical composition, Atmos. Environ., 34, 4853-4857, doi:10.1016/S1352-2310(00)00237-5, 2000.

Feingold, G. and Chuang, P. Y.: Analysis of the Influence of Film-Forming Compounds on Droplet Growth: Implications for Cloud Microphysical Processes and Climate, J. Atmos. Sci., 59, 2006-2018, doi:10.1175/1520-0469(2002)059<2006:AOTIOF> 2.0.CO;2, 2002.

Gautam, K. K. and Tyagi, V. K.: Microbial Surfactants: A Review, J. Oleo Sci., 55, 155-166, doi:10.5650/jos.55.155, 2006.

Gérard, V., Nozière, B., Baduel, C., Fine, L., Frossard, A. A., and Cohen, R. C.: Anionic, Cationic, and Nonionic Surfactants in Atmospheric Aerosols from the Baltic Coast at Askö, Sweden: Implications for Cloud Droplet Activation, Environ. Sci. Technol., 50, 2974-2982, doi:10.1021/acs.est.5b05809, 2016.

Gill, P. S., Graedel, T. E., and Weschler, C. J.: Organic films on atmospheric aerosol particles, fog droplets, cloud droplets, raindrops, and snowflakes, Rev. Geophys., 21, 903-920, doi:10.1029/RG021i004p00903, 1983.

Gilman, J. B. and Vaida, V.: Permeability of Acetic Acid through Organic Films at the Air-Aqueous Interface, J. Phys. Chem. A, 110, 7581-7587, doi:10.1021/jp061220n, 2006.

Hansen, F. K. and Rødsrud, G.: Surface tension by pendant drop, J. Colloid Interface Sci., 141, 1-9, doi:10.1016/00219797(91)90296-K, 1991.

Hejkal, T. W., LaRock, P. A., and Winchester, J. W.: Water-to-Air Fractionation of Bacteria, Appl. Environ. Microbiol., 39, 335338, 1980.

Herckes, P., Valsaraj, K. T., and Collett, J. L.: A review of observations of organic matter in fogs and clouds: Origin, processing and fate, Atmos. Res., 132-133, 434-449, doi:10.1016/j.atmosres.2013.06.005, 2013.

Hill, K. A., Shepson, P. B., Galbavy, E. S., Anastasio, C., Kourtev, P. S., Konopka, A., and Stirm, B. H.: Processing of atmospheric nitrogen by clouds above a forest environment, J. Geophys. Res.Atmos., 112, D11301, doi:10.1029/2006jd008002, 2007.

Hitzenberger, R., Berner, A., Kasper-Giebl, A., Löflund, M., and Puxbaum, H.: Surface tension of Rax cloud water and its relation to the concentration of organic material, J. Geophys. Res.Atmos., 107, 4752, doi:10.1029/2002JD002506, 2002.

Hua, X. Y. and Rosen, M. J.: Dynamic surface tension of aqueous surfactant solutions, J. Colloid Interf. Sci., 141, 180-190, doi:10.1016/0021-9797(91)90313-W, 1991.

Jackson, S. A., Borchert, E., O'Gara, F., and Dobson, A. D. W.: Metagenomics for the discovery of novel biosurfactants of environmental interest from marine ecosystems, Curr. Opin. Biotech., 33, 176-182, doi:10.1016/j.copbio.2015.03.004, 2015.

Janek, T., Łukaszewicz, M., and Krasowska, A.: Identification and characterization of biosurfactants produced by the Arctic bacterium Pseudomonas putida BD2, Colloid. Surface B, 110, 379386, doi:10.1016/j.colsurfb.2013.05.008, 2013.

Joly, M., Amato, P., Sancelme, M., Vinatier, V., Abrantes, M., Deguillaume, L., and Delort, A.-M.: Survival of microbial isolates from clouds toward simulated at- 
mospheric stress factors, Atmos. Environ., 117, 92-98, doi:10.1016/j.atmosenv.2015.07.009, 2015.

Kanakidou, M., Seinfeld, J. H., Pandis, S. N., Barnes, I., Dentener, F. J., Facchini, M. C., Van Dingenen, R., Ervens, B., Nenes, A., Nielsen, C. J., Swietlicki, E., Putaud, J. P., Balkanski, Y., Fuzzi, S., Horth, J., Moortgat, G. K., Winterhalter, R., Myhre, C. E. L., Tsigaridis, K., Vignati, E., Stephanou, E. G., and Wilson, J.: Organic aerosol and global climate modelling: a review, Atmos. Chem. Phys., 5, 1053-1123, doi:10.5194/acp-5-1053-2005, 2005.

Karanth, N. G. K., Deo, P. G., and Veenanadig, N. K.: Microbial production of biosurfactants and their importance, Curr. Sci., 77, 116-126, 1999.

King, E. O., Ward, M. K., and Raney, D. E.: Two simple media for the demonstration of pyocyanin and fluorescin, J. Lab. Clin. Med., 44, 301-307, 1954.

Kiss, G., Tombácz, E., and Hansson, H.-C.: Surface Tension Effects of Humic-Like Substances in the Aqueous Extract of Tropospheric Fine Aerosol, J. Atmos. Chem., 50, 279-294, doi:10.1007/s10874-005-5079-5, 2005.

Köhler, H.: The nucleus in and the growth of hygroscopic droplets, T. Faraday Soc., 32, 1152, doi:10.1039/tf9363201152, 1936.

Lance, S., Nenes, A., and Rissman, T. A.: Chemical and dynamical effects on cloud droplet number: Implications for estimates of the aerosol indirect effect, J. Geophys. Res.-Atmos., 109, D22208, doi:10.1029/2004JD004596, 2004.

Li, X., Hede, T., Tu, Y., Leck, C., and Ågren, H.: Surface-Active cisPinonic Acid in Atmospheric Droplets: A Molecular Dynamics Study, J. Phys. Chem. Lett., 1, 769-773, doi:10.1021/jz9004784, 2010.

Li, Y., Ezell, M. J., and Finlayson-Pitts, B. J.: The impact of organic coatings on light scattering by sodium chloride particles, Atmos. Environ., 45, 4123-4132, doi:10.1016/j.atmosenv.2011.05.031, 2011

Lo, J.-H. A. and Lee, W.-M. G.: Effect of surfactant film on solubility of hydrophobic organic compounds in fog droplets, Chemosphere, 33, 1391-1408, doi:10.1016/0045-6535(96)00273-1, 1996.

Mann, E. E. and Wozniak, D. J.: Pseudomonas biofilm matrix composition and niche biology, FEMS Microbiol. Rev., 36, 893-916, doi:10.1111/j.1574-6976.2011.00322.x, 2012.

McDonald, B. A. and Linde, C.: The population genetics of plant pathogens and breeding strategies for durable resistance, Euphytica, 124, 163-180, doi:10.1023/A:1015678432355, 2002.

McFiggans, G., Artaxo, P., Baltensperger, U., Coe, H., Facchini, M. C., Feingold, G., Fuzzi, S., Gysel, M., Laaksonen, A., Lohmann, U., Mentel, T. F., Murphy, D. M., O’Dowd, C. D., Snider, J. R., and Weingartner, E.: The effect of physical and chemical aerosol properties on warm cloud droplet activation, Atmos. Chem. Phys., 6, 2593-2649, doi:10.5194/acp-6-2593-2006, 2006.

Ministère de l'Agriculture, de l'Agroalimentaire et de la Forêt: Agreste La statistique, l'évaluation et la prospective agricole, Territoire et climat., [online] Available at: http://agreste. agriculture.gouv.fr/IMG/pdf/Gaf15p013-017.pdf (last access: 20 May 2016), 2014.

Mircea, M., Facchini, M. C., Decesari, S., Fuzzi, S., and Charlson, R. J.: The influence of the organic aerosol component on CCN supersaturation spectra for different aerosol types, Tellus B, 54, 74-81, doi:10.1034/j.1600-0889.2002.00256.x, 2002.
Mircea, M., Facchini, M. C., Decesari, S., Cavalli, F., Emblico, L., Fuzzi, S., Vestin, A., Rissler, J., Swietlicki, E., Frank, G., Andreae, M. O., Maenhaut, W., Rudich, Y., and Artaxo, P.: Importance of the organic aerosol fraction for modeling aerosol hygroscopic growth and activation: a case study in the Amazon Basin, Atmos. Chem. Phys., 5, 3111-3126, doi:10.5194/acp-53111-2005, 2005.

Morris, C. E., Sands, D. C., Vinatzer, B. A., Glaux, C., Guilbaud, C., Buffière, A., Yan, S., Dominguez, H., and Thompson, B. M.: The life history of the plant pathogen Pseudomonas syringae is linked to the water cycle, ISME J., 2, 321-334, 2008.

Morris, C. E., Conen, F., Alex Huffman, J., Phillips, V., Pöschl, U., and Sands, D. C.: Bioprecipitation: a feedback cycle linking Earth history, ecosystem dynamics and land use through biological ice nucleators in the atmosphere, Glob. Change Biol., 20, 341-351, doi:10.1111/gcb.12447, 2014.

Mulligan, C. N.: Recent advances in the environmental applications of biosurfactants, Curr. Opin. Colloid In., 14, 372-378, doi:10.1016/j.cocis.2009.06.005, 2009.

Murphy, D. M., Cziczo, D. J., Froyd, K. D., Hudson, P. K., Matthew, B. M., Middlebrook, A. M., Peltier, R. E., Sullivan, A., Thomson, D. S., and Weber, R. J.: Single-particle mass spectrometry of tropospheric aerosol particles, J. Geophys. Res., 111, doi:10.1029/2006JD007340, 2006.

Nenes, A., Charlson, R. J., Facchini, M. C., Kulmala, M., Laaksonen, A., and Seinfeld, J. H.: Can chemical effects on cloud droplet number rival the first indirect effect?, Geophys. Res. Lett., 29, 1848, doi:10.1029/2002GL015295, 2002.

Nozière, B.: Don't forget the surface, Science, 351, 1396-1397, doi:10.1126/science.aaf3253, 2016.

Nozière, B., Baduel, C., and Jaffrezo, J.-L.: The dynamic surface tension of atmospheric aerosol surfactants reveals new aspects of cloud activation, Nat. Commun., 5, 3335, doi:10.1038/ncomms4335, 2014.

O’Dowd, C. D., Aalto, P., Hmeri, K., Kulmala, M., and Hoffmann, T.: Aerosol formation: Atmospheric particles from organic vapours, Nature, 416, 497-498, doi:10.1038/416497a, 2002.

Olkowska, E., Ruman, M., and Polkowska, Ż.: Occurrence of Surface Active Agents in the Environment, J. Anal. Methods Chem., 2014, e769708, doi:10.1155/2014/769708, 2014.

Park, S.-C., Burden, D. K., and Nathanson, G. M.: Surfactant Control of Gas Transport and Reactions at the Surface of Sulfuric Acid, Acc. Chem. Res., 42, 379-387, doi:10.1021/ar800172m, 2009.

Prisle, N. L., Ottosson, N., Öhrwall, G., Söderström, J., Dal Maso, M., and Björneholm, O.: Surface/bulk partitioning and acid/base speciation of aqueous decanoate: direct observations and atmospheric implications, Atmos. Chem. Phys., 12, 12227-12242, doi:10.5194/acp-12-12227-2012, 2012.

Raaijmakers, J. M., Bruijn, I. D., Nybroe, O., and Ongena, M.: Natural functions of lipopeptides from Bacillus and Pseudomonas: more than surfactants and antibiotics, FEMS Microbiol. Rev., 34, 1037-1062, doi:10.1111/j.1574-6976.2010.00221.x, 2010.

Reasoner, D. J. and Geldreich, E. E.: A new medium for the enumeration and subculture of bacteria from potable water, Appl. Environ. Microbiol., 49, 1-7, 1985.

Renard, P., Reed Harris, A. E., Rapf, R. J., Ravier, S., Demelas, C., Coulomb, B., Quivet, E., Vaida, V., and Monod, A.: Aqueous Phase Oligomerization of Methyl Vinyl Ketone by Atmo- 
spheric Radical Reactions, J. Phys. Chem. C, 118, 29421-29430, doi:10.1021/jp5065598, 2014.

Rodhe, H.: Atmospheric chemistry: Clouds and climate, Nature, 401, 223-225, doi:10.1038/45701, 1999.

Ron, E. Z. and Rosenberg, E.: Natural roles of biosurfactants, Environ. Microbiol., 3, 229-236, doi:10.1046/j.14622920.2001.00190.x, 2001.

Rosenberg, E. and Ron, E. Z.: High- and low-molecular-mass microbial surfactants, Appl. Microbiol. Biot., 52, 154-162, doi:10.1007/s002530051502, 1999.

Rudich, Y.: Laboratory Perspectives on the Chemical Transformations of Organic Matter in Atmospheric Particles, Chem. Rev., 103, 5097-5124, doi:10.1021/cr020508f, 2003.

Ruehl, C. R., Chuang, P. Y., Nenes, A., Cappa, C. D., Kolesar, K. R., and Goldstein, A. H.: Strong evidence of surface tension reduction in microscopic aqueous droplets, Geophys. Res. Lett., 39, L23801, doi:10.1029/2012GL053706, 2012.

Ruehl, C. R., Davies, J. F., and Wilson, K. R.: An interfacial mechanism for cloud droplet formation on organic aerosols, Science, 351, 1447-1450, doi:10.1126/science.aad4889, 2016.

Sareen, N., Schwier, A. N., Lathem, T. L., Nenes, A., and McNeill, V. F.: Surfactants from the gas phase may promote cloud droplet formation, P. Natl. Acad. Sci. USA, 110, 2723-2728, doi:10.1073/pnas.1204838110, 2013.

Satpute, S. K., Banat, I. M., Dhakephalkar, P. K., Banpurkar, A. G., and Chopade, B. A.: Biosurfactants, bioemulsifiers and exopolysaccharides from marine microorganisms, Biotechnol. Adv., 28, 436-450, doi:10.1016/j.biotechadv.2010.02.006, 2010.

Sattler, B., Puxbaum, H., and Psenner, R.: Bacterial growth in supercooled cloud droplets, Geophys. Res. Lett., 28, 239-242, doi:10.1029/2000GL011684, 2001.

Saxena, P. and Hildemann, L. M.: Water-soluble organics in atmospheric particles: A critical review of the literature and application of thermodynamics to identify candidate compounds, J. Atmos. Chem., 24, 57-109, doi:10.1007/BF00053823, 1996.

Seidl, W. and Hänel, G.: Surface-active substances on rainwater and atmospheric particles, Pure Appl. Geophys., 121, 1077-1093, 1983.

Shulman, M. L., Jacobson, M. C., Carlson, R. J., Synovec, R. E., and Young, T. E.: Dissolution behavior and surface tension effects of organic compounds in nucleating cloud droplets, Geophys. Res. Lett., 23, 277-280, doi:10.1029/95GL03810, 1996.
Sorjamaa, R., Svenningsson, B., Raatikainen, T., Henning, S., Bilde, M., and Laaksonen, A.: The role of surfactants in Köhler theory reconsidered, Atmos. Chem. Phys., 4, 2107-2117, doi:10.5194/acp-4-2107-2004, 2004.

Svenningsson, B., Rissler, J., Swietlicki, E., Mircea, M., Bilde, M., Facchini, M. C., Decesari, S., Fuzzi, S., Zhou, J., Mønster, J., and Rosenørn, T.: Hygroscopic growth and critical supersaturations for mixed aerosol particles of inorganic and organic compounds of atmospheric relevance, Atmos. Chem. Phys., 6, 1937-1952, doi:10.5194/acp-6-1937-2006, 2006.

Taraniuk, I., Graber, E. R., Kostinski, A., and Rudich, Y.: Surfactant properties of atmospheric and model humiclike substances (HULIS), Geophys. Res. Lett., 34, L16807, doi:10.1029/2007GL029576, 2007.

Vaïtilingom, M., Attard, E., Gaiani, N., Sancelme, M., Deguillaume, L., Flossmann, A. I., Amato, P., and Delort, A.-M.: Long-term features of cloud microbiology at the puy de Dôme (France), Atmos. Environ., 56, 88-100, doi:10.1016/j.atmosenv.2012.03.072, 2012.

Vaïtilingom, M., Deguillaume, L., Vinatier, V., Sancelme, M., Amato, P., Chaumerliac, N., and Delort, A.-M.: Potential impact of microbial activity on the oxidant capacity and organic carbon budget in clouds, P. Natl. Acad. Sci. USA, 110, 559-564, doi:10.1073/pnas.1205743110, 2013.

Zenchelsky, S. and Youssefi, M.: Natural organic atmospheric aerosols of terrestrial origin, Rev. Geophys., 17, 459-464, doi:10.1029/RG017i003p00459, 1979.

Zhang, Q., Jimenez, J. L., Canagaratna, M. R., Allan, J. D., Coe, H., Ulbrich, I., Alfarra, M. R., Takami, A., Middlebrook, A. M., Sun, Y. L., Dzepina, K., Dunlea, E., Docherty, K., DeCarlo, P. F., Salcedo, D., Onasch, T., Jayne, J. T., Miyoshi, T., Shimono, A., Hatakeyama, S., Takegawa, N., Kondo, Y., Schneider, J., Drewnick, F., Borrmann, S., Weimer, S., Demerjian, K., Williams, P., Bower, K., Bahreini, R., Cottrell, L., Griffin, R. J., Rautiainen, J., Sun, J. Y., Zhang, Y. M., and Worsnop, D. R.: Ubiquity and dominance of oxygenated species in organic aerosols in anthropogenically-influenced Northern Hemisphere midlatitudes, Geophys. Res. Lett., 34, L13801, doi:10.1029/2007GL029979, 2007. 